\title{
The Contribution of Internship Program 1 and 2 on the Student's Learning Commitment at Faculty of Educational Unimed
}

\author{
Yasaratodo $\mathrm{Wau}^{1}$, Rahmatsyah ${ }^{2}$,Tri Andri Hutapea ${ }^{3}$ \\ \{yasaratodo@gmail.com\} \\ Universitas Negeri Medan,Jl. Willem Iskandar / Pasar V, Medan, Indonesia ${ }^{1,2,3}$
}

\begin{abstract}
This research examines the issues of (1) how's the perceptions of students about the activities implementation policy on Internship program 1 and 2, at Unimed (2) How's the learning commitment of FIP college students of Unimed, and (3) contribution analysis of implementation policy on Internship activities 1 and 2 against College Student Learning Commitment FIP Unimed.This research was carried out in the Faculty of Education (FIP) Unimed for 645 college students all over the 2016/2017 academic year that have been doing Internship Program 1 and 2 in the sample unit of education as research population, and the research has been specified using random sampling technique as many as 141 students. This research data collected with the use of a questionnaire instrument with Likert Scale patterns and student learning outcomes in the form of Grade Point Average (GPA). This research data is processed by using the descriptive correlation technique, by performing a test of its homogeneity and normality of variables, test requirements analysis, and test the hypothesis by using t test. The findings of this research are expected to be signaled that the internship activities 1 and 2 have a pretty mean benefits against the formation of student learning commitment so that it can develop the right learning motivation in achieving maximal activity success on lecture.
\end{abstract}

Keywords: Contribution, Internship Program, Commitment, Learning.

\section{Introduction}

Students as learners at the college level are always the concern of decision makers and/or policies. Various policies are stipulated as guidelines in producing students while in college, where they are always accompanied, guided, directed, and motivated to learn, learn, learn with various approaches, methods, and techniques that are well designed by managers and their education personnel.

Since the 2016/2017 academic year, Unimed has established policies in the curriculum field, which is applying the Indonesian National Qualification Framework Curriculum model in which academic activities refer to learning outcomes which are the internalization and accumulation of knowledge, skills, attitudes and competencies that can be achieved through structured education and training processes that cover certain fields of science or expertise. This policy is in line with the spirit of Permenristekdikti No. 55 of 2017 which makes schools as a place to practice acquiring teaching competencies, both for undergraduate education programs through Introduction to School Fields and for teacher professional education through Field Experience Practices. 
Field Experience Practice for students in previous years was held in the sixth semester. Through the policy of the Unimed Leaders, all students in the 2016/2017 academic year are required to attend the Internship Course, with three stages, namely (1) Internship 1, the stages of observation of classroom practice and the management and implementation of school curriculum, in the second semester; (2) Internship 2, which is Stages of reviewing the practical aspects of the school curriculum and its application in the classroom that is associated with Unimed lectures,in the fourth semester; and (3) Internship 3, namely the Teaching Implementation Plan preparation phase and its implementation based on its relevance to lectures in Unimed, on sixth semester.

This Unimed Leadership Policy has lasted 2 years and the 2017/208 academic year has entered its second year (fourth semester) for students in 2016/2017 (Internship 2). How far the impact on student learning commitment is a question that needs to be analyzed. Analysis can be done in various ways, and among them are predicted to be more accurate by conducting scientific research. Through research studies that have been carried out, it has obtained a signal that Internship I has a relationship with the commitment of students to prepare themselves to become Candidates for Educators and / or educational staff in FIP, especially in the Unimed PLS FIP Study Program with a correlation coefficient of 0.49 and the amount of contribution is 24.6 percent (Wau, 2017). About how can be the same thing achieved by other study programs, so far no significant data has been obtained. The importance of the learning experience of this apprenticeship program has also been investigated by several experts, including (1) Ashland who's in collaboration with universities and students (1996), (2) Deen Lango (2018), (3) Luka bakar (2017), (4) Dove Terrence (2017), and (5) Lewis Anne C (2004) in providing them with a number of learning experiences that are useful in the formation of various learning skills including learning commitment building.

Learning commitment is the determination or promise of students to themselves to do all the learning activities that have been determined by the institution that organizes the study program in universities.

How far the results of internship courses 1 and 2 can realize or influence student learning in preparation to become professional educator candidates and / or teaching staff will need to be studied scientifically through research entitled "Analysis of the Contribution of Internship 1 and 2 Subjects to Learning Commitments of Unimed FIP Students ".

\section{A. Formulation of the Problem}

Based on the background of the problems raised above, the problem of this research can be formulated as follows:

1. How is the student's perception of the results of the Implementation of Internship 1 and 2 in FIP Unimed

2. How is the student's learning commitment in preparing themselves to become Prospective Educators and / or educational staff in Unimed FIP

3. How is the Contribution of Perception to Internship Courses 1 and 2 to Student Commitment in Unimed FIP 


\section{B. Literature Review}

\section{Student Learning Commitment}

Learning commitment describes a situation in which students state their commitment or motivation to do learning activities seriously. This is consistent with the concept of organizational commitment proposed by Robbin (2006: 94-95) that organizational commitment shows the involvement of members in an organization that describes the willingness of members to side with certain work that has been determined. In a writing of a student in Doctoral Program on the "Learning Commitment / My Ph.D Life" page, Chrisphdlife with the title "we need more commitment than motivation" (https://chrisphdlife.wordpress.com/tag/ commitment-learning /) revealed that "commitment comes from within ourselves about how much consistency we do what is planned. Commitment is not based on feelings (like it or not, enthusiasm, or not).

Prayitno (2009) states that commitment is the willpower, firmness of attitude, and seriousness of determination, to do better, not to repeat the wrong actions or violate it; will not do the same thing in the same place or elsewhere. likewise Luthans (2006) explains that organizational commitment can be defined as (1) a strong desire to remain as a member of a particular organization, (2) a desire to strive according to the desires of the organization, and 3 ) certain beliefs, and acceptance of organizational values and goals, so it can be synthesized that student learning commitment is as (1) a strong desire to remain as a student in the chosen department, (2) a desire to strive according to the study program's wishes, and 3) certain beliefs, and acceptance of the values and objectives of the department or study program

\section{The Nature of Internship Studies}

Internships are generally defined as part of a job training system that is held in an integrated manner between training in training institutions by working directly under the guidance and supervision of instructors or workers who are more experienced in the production process of goods and / or services in the company, in order to master skills or certain expertise (Minister of Manpower and Transmigration Regulation No. Per.22/Men/IX/2009 concerning Implementation of Internship in the Country).

Internships that are briefly stated above, at the tertiary level, especially at the State University of Medan (Unimed) which have made fundamental changes in the implementation of the Indonesian National Qualifications Framework (KKNI) curriculum, make it an internship course for educational and non-education study programs. This internship program is a compulsory subject for all students in Unimed, with three stages, namely (1) Internship 1, (2) Internship 2, and (3) Internship 3 (Unimed, 2017)

The Internship program designed in the Unimed curriculum provides benefits to various parties, especially students, which include (1) Students can apply and enhance the knowledge gained in the lecture bench, (2) Improve the ability of students to master professional competence in the field of gradual science (3) The opportunity to establish self-confidence and improve professional skills and expertise, (4) Obtain understanding, appreciation, and experience in the field of the education profession, (5) Gain experience through observation of the process of forming competencies in the field of science in the field, (6) Obtain experience about how to think and work interdisciplinaryly, and (7) Obtain reasoning ability in conducting research, formulation and problem solving of professional fields in the business world. 
The objectives and benefits of the internship above, especially Internships 1 and 2, will be achieved if students can cooperate with parties that are directly related to the study program and the educational institution / unit where the Internship 1 is held. The learning activities that students have to do in Internship 1 have been designed in such a way by universities and study programs, which include observations of the Education Unit consisting of (1) management unit education culture, (2) educator competence, and (3) students, (4) the learning process in the classroom, a reflection of the results of the learning process, while the second internship was given the experience of developing learning tools by (1) studying the curriculum, (2) studying learning strategies, (3) reviewing the assessment system, (4) designing learning preparation, (5) developing media, learning materials and devices.

\section{Method}

Learning commitment of students in Education Personnel of Education Institutions to prepare as professional educators and/or education personnel can be determined by many factors both from themselves and from outside themselves. If the encouragement from outside is the chosen institution/study program in the form of providing various types and levels of lecture activities as outlined in the curriculum, syllabus, learning implementation plan that must be done by students, then the perception factor from within the student will determine how to respond to and implement everything the type and level of activities programmed by the study program.

The policy of applying for Internship Courses can also be predicted to provide opportunities for students to reflect on activities while attending or doing the Eye of Internship 1 and 2. The results of these reflections can be decisive for students to think about, analyze, and decide again on their learning commitments in their chosen study program. Students who already have an understanding of the ins and outs of organizing education and learning activities in schools and teachers who must be professional in teaching their students will encourage themselves to have a high learning commitment to prepare themselves to become professional education candidates in the field of science they conduct.

Based on the mindset above it can be synthesized that the policy of applying Internship Courses for students at Unimed has encouraged the importance of being studied more deeply the contribution of Internship Courses 1 and 2 to the learning commitment of students in universities, especially in the Unimed Faculty of Education. with the research paradigm as follows:

\section{Conclusion}

Based on the above framework, it can be concluded that the policy of applying Internship Courses at Unimed has encouraged the importance of further study about how far the policy contributes to student learning commitment and as a follow-up of this study, data collection will be conducted to prove the following hypothesis. "There are significant contributions in 1 and 2 Internship Courses on Learning Commitments for Students in Unimed FIP ". 


\section{References}

[1] Ashland: Ashaland Work with University, Student. Foundry Manajement \& Teknology Nov 95. Education Association. (1996)

[2] DeenLango: BuildingA Career Step by Step. Hispanik Engineer \& Information Tecnology. Jurnal EBSCO 2018 Industries (2018)

[3] Dove Terrence: Internship: 7 Thing You Need to Know. Jurnal US Black Engineer \&Information Technology (2017)

[4] Echols, John M.: Kamus Inggris Indonesia. Gramedia, Jakarta (2003)

[5] Lewis Anne C.: Year Up's. Tech Direction. EBSCO 2018 Industries Ins (2004)

[6] Luka bakar: Meta Analisis Pengaruh Keterlibatan Industri pada Pembelajaran Siswa dalam Program Sarjana. Jurnal Teknologi Manajemen dan Teknologi Terapan (2004)

[7] Luthans \& Fred: Perilaku Organisasi; Edisi Kesepuluh; Penerjemah: Vivin Andhika Yuwono, dkk. (2006)

[8] Mowday, 1982. http://jurnal-sdm.blogspot.com/2009/07/komitmen-karyawan-definisi-danjenis.html.

[9] Prayitno: Dasar Teori dan Praksis Pendidikan. Gramedia, Jakarta (2009)

[10] Peraturan Menteri Tenaga Kerjadan Transmigrasi No. Per.22/Men/IX/2009 tentang Penyelenggaraan Pemagangan di Dalam Negeri

[11] Rakhmat \& Jalaluddin: Psikologi Komunikasi. Edisi Revisi. Remaja Rosdakarya, Bandung (2005)

[12] Robbins \& Stephen P.: Perilaku Organisasi. Edisi Kesepuluh. Alih Bahasa Drs. Benyamin Molan. kelompok Gramedia, Jakarta (2006)

[13] Unimed: Pedoman Pelaksanaan Magang di Unimed. Unimed, Medan (2017)

[14] Wau, Yasaratodo, Anifah, \& Fauzi K.: Persepsi Tentang Hasil Refleksi Penyelenggaraan Kegiatan Magang 1 dan Hubungannya dengan Komitmen Mahasiswa Membekali Diri Menjadi Calon Tenaga Pendidikan di Program Studi Pendidikan Luar Sekolah FIP Unimed, Medan (2017)

[15] http://id.shvoong.com/social-sciences/psychology/1837978-definisi-persepsi

[16] https://chrisphdlife.wordpress.com/tag/komitmen-belajar/ 